\title{
1. THE VOLCANIC RECORD OF THE RÉUNION HOTSPOT ${ }^{1}$
}

\author{
Robert A. Duncan ${ }^{2}$
}

\begin{abstract}
The hotspot now producing magma beneath the volcanic island of Réunion burst into activity with massive volumes of rapidly erupted flood basalts over much of western India at the time of the Cretaceous/Tertiary boundary ( $66 \mathrm{Ma})$. Subsequent products from this hotspot became the volcanic foundations of the Laccadives and Maldives ridges, the Chagos Bank, and much of the Mascarene Plateau, including the young volcanic islands of Mauritius and Rodrigues. The linear geometry of these volcanic ridges and their north-to-south age progression are compatible with motion of, first, the Indian and, more recently, the African plates over a stationary hotspot beneath Réunion. This focused, upper mantle melting anomaly has remained fixed with respect to other prominent hotspots in the Atlantic and Indian ocean basins and provides a ready frame of reference for plate reconstruction surrounding the western Indian Ocean. A comparison of site paleolatitude samples in the hotspot and paleomagnetic reference frames reveals a gradual shift of the mantle with respect to the earth's spin axis through Tertiary time. Basalt compositions along the hotspot track vary systematically in response to changes in the relative positions of spreading ridges and the hotspot during the opening of the Indian Ocean and to secular changes in the output of the hotspot.
\end{abstract}

\section{INTRODUCTION}

That linear, age-progressive volcanic activity in the ocean basins and on continents is linked to focused, relatively fixed upper mantle melting anomalies, termed "hotspots," is now well established. It also seems clear that hotspots are very long-lived features that produce magmas geochemically distinct from those erupted at spreading ridges. The longevity, stability, and compositional identity of hotspots favor a model in which hotter than surrounding mantle material (and/or material that melts at lower temperatures) is continually supplied to the melting zone by convective plumes from deeper regions of the mantle. The ultimate composition and source region of mantle plumes, the mechanism and time scale for convective instabilities that initiate plumes, and the size, longevity, and magnitude of hotspot drifts are all subjects of considerable speculation.

The Indian Ocean basin is a particularly fruitful region to study the behavior of hotspots and mantle plumes. Rapid plate velocities have produced clear linear volcanic ridges, which strongly limit estimates of motion between hotspots, and plate boundary jumps have changed the relative positions of hotspots and spreading ridges, allowing the examination of a range of possible mantle source compositions in various mixing proportions. It is also intriguing that the initial phase of hotspot activity may be preserved as vast accumulations of continental and oceanic plateau tholeiitic flood basalts.

The two major hotspot traces in the Indian Ocean basin are those left by the Réunion and the Kerguelen hotspots (Morgan, 1981). The western (Réunion) province includes the Mascarene Islands, the Mascarene Plateau, the Chagos-Maldives-Laccadives ridges, and the Deccan flood basalts, whereas the eastern (Kerguelen) province includes the Kerguelen Archipelago, the Kerguelen Plateau, the Broken and Ninetyeast ridges, and the Rajmahal flood basalts (Morgan, 1981; Duncan, 1978, 1981). These volcanic trails preserve an unusually complete record of the activity of mantle plumes, from their birth in catastrophic flood

\footnotetext{
${ }^{1}$ Duncan, R. A., Backman, J., Peterson, L. C., et al., 1990. Proc. ODP, Sci. Results, 115: College Station, TX (Ocean Drilling Program).

2 College of Oceanography, Oregon State University, Corvallis, OR 97331,
}

basalt events (Morgan, 1981; Richards et al., 1989) through maturity, feeding continuous volcanic ridges, into decline as discrete islands marking intermittent hotspot activity.

Deep drilling to recover basement rocks during Ocean Drilling Program (ODP) Leg 115 was the first segment of a program of sampling the products of hotspot volcanism in the Indian Ocean; Legs 119 and 120 recovered basalts from four sites on the Kerguelen Plateau and Leg 121 drilled three basement sites along the Ninetyeast Ridge. A complete synthesis of results from the entire Indian Ocean hotspot drilling program will await the analytical studies on basaltic samples cored during the later legs. The purpose of this paper is to summarize the conclusions from shipboard and shore-based studies of Leg 115 basement rocks regarding the history of the Réunion hotspot. Other papers in this volume report detailed investigations of basalt compositions, including major and trace elements (Baxter; Greenough and Fryer), isotopes (White et al.; Tatsumi and Nohda), mineralogy (Fisk and Howard; Hargraves), and secondary alteration (Greenough et al.; Fisk and Howard). The age distribution of volcanic rocks along the lineament (Duncan and Hargraves) and paleomagnetic studies (Vandamme and Courtillot; Schneider and Kent; Hargraves and Duncan) provide a basis for examining temporal variations and plate reconstructions in the hotspot and paleomagnetic reference frames.

\section{PHYSICAL AND TEMPORAL EXPRESSION OF THE RÉUNION HOTSPOT}

The hypothesized trace of the Réunion hotspot (Morgan, 1981) trends northeastward from the islands of Réunion and Mauritius, along the eastern limb of the Mascarene Plateau formed by the Cargados Carajos and Nazareth banks (Fig. 1). Rodrigues Island lies at the eastern end of a short volcanic ridge that intersects the southern end of the Mascarene Plateau; it is probable that this feature is related to Réunion hotspot activity, although its orientation is not readily explained by known plate motion over the fixed hotspot. Morgan (1987) proposed that the Rodrigues Ridge formed from channeled asthenospheric flow from the hotspot to the nearby spreading ridge. Its orientation was determined by the vector sum of African plate motion over the hotspot and the relative motion of the spreading ridge away from the plate. If this is the case, we can expect that the age of volcanism will decrease from west to east. 


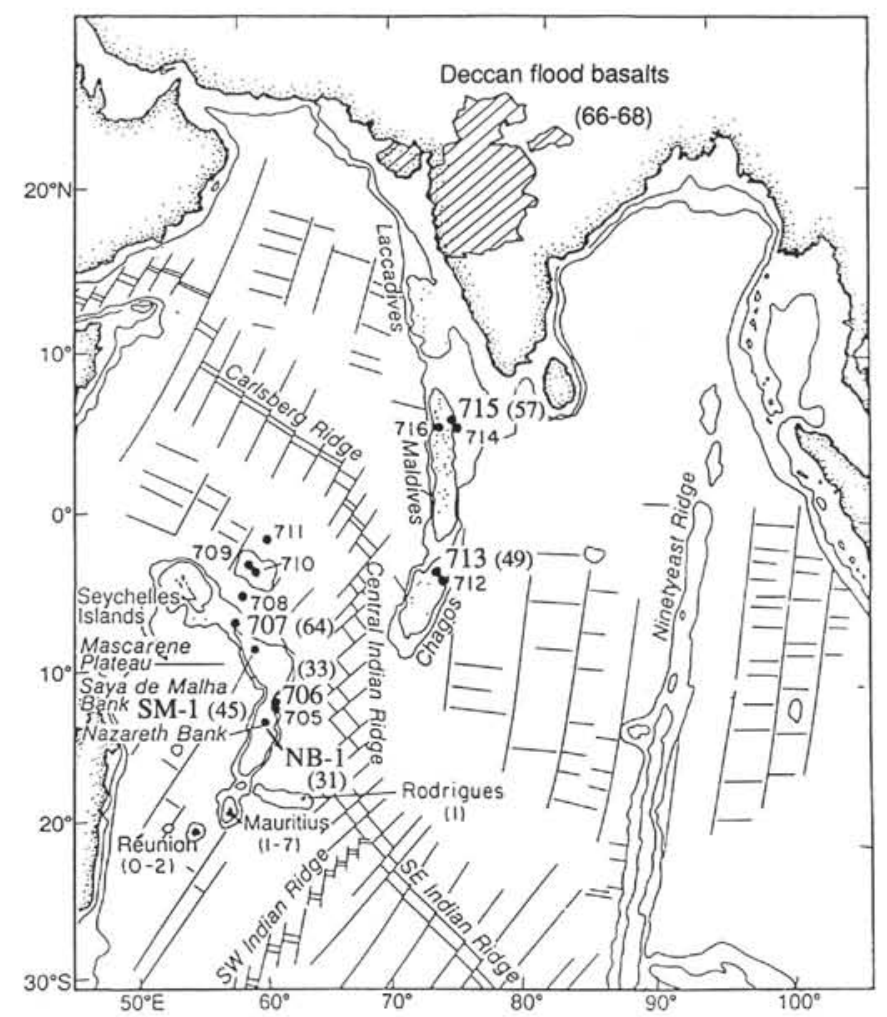

Figure 1. Geographic elements of the volcanic trail of the Réunion hotspot, western Indian Ocean, and sample sites from Leg 115 drilling, industry wells, and subaerial exposures. Larger numbers indicate those sites that penetrated basement rocks. Radiometric ages are indicated (Ma) and are described in Duncan and Hargraves (this volume).

The Saya de Malha Bank has been considered a submerged, southeastward extension of the late Precambrian Seychelles microcontinent (McKenzie and Sclater, 1971) or a volcanic platform formed either as part of the Deccan flood basalts (Courtillot et al., 1986) or during a later episode of the hotspot's activity. An older section of the hotspot track, starting with the Chagos Bank, was separated from the younger Mascarene Plateau by post-Eocene spreading at the Central Indian Ridge (McKenzie and Sclater, 1971; Schlich, 1982; Patriat et al., 1982). From the Chagos Bank, the hotspot trace follows the Maldives and Laccadives ridges and finally ends at the Deccan flood basalt province in western India (Fig. 1).

In addition to subaerially erupted basalts at the northern and southern ends of this volcanic lineament, deep drilling at industry wells on the Nazareth and Saya de Malha banks and on the Maldives Ridge have penetrated great thicknesses of basaltic rocks (Meyerhoff and Kamen-Kaye, 1981). Dredged rocks were obtained from the Rodrigues Ridge during Darwin site-survey cruise $21 / 87$ before Leg 115 . Submarine drilling at four new locations during Leg 115 successfully sampled the volcanic rocks underlying the carbonate platform that covers the Mascarene Plateau and the Chagos-Maldives-Laccadives ridge system (Fig. 1). Thus, there are samples from ten geographically and temporally distinct sites from which to examine the evolution of the Réunion hotspot.

Presently, the hotspot lies beneath the old oceanic lithosphere on which the island of Réunion is being built. This island is constructed from two coalesced volcanoes: Piton des Neiges, which is inactive and forms the northwest two-thirds of the island, and the active Piton de la Fournaise, which regularly erupts magma and forms the southeastern third of the island. A large seamount $160 \mathrm{~km}$ west of Réunion may be the newest volcanic product of the hotspot. McDougall (1971) determined radiometric ages for the subaerial portions of the Mascarene Islands, which rise up to $7000 \mathrm{~m}$ from the seafloor. Volcanic activity at Réunion is at least as old as $2 \mathrm{Ma}$ and continues today at Piton de la Fournaise. Estimates of average eruption rates over the hotspot are 0.01-0.04 km³ $/ \mathrm{yr}$ (Richards et al., 1989; Gillot and Nativel, 1989).

The eroded volcanic island of Mauritius, some $200 \mathrm{~km}$ northeast of Réunion, has had an extended eruptive history, starting with a shield-building phase at 7-8 Ma, with later stages at 23.5 and $0.2-0.7 \mathrm{Ma}$. For all eruptions to be related directly to the hotspot, the melting zone would have to be enormous (radius $=400 \mathrm{~km}$ ), yet we see no evidence of volcanic activity between Réunion and Mauritius. It seems more probable that the rejuvenescent phases of volcanism at Mauritius occurred as the underlying lithosphere, domed and loaded over the hotspot, began to cool and subside downstream from the melting zone. In this case, fracturing caused by thermal and bending stresses could allow small volumes of magmas to rise from the asthenosphere, as has been proposed for the Hawaiian post-erosional lavas (Ten Brink et al., 1986).

Rodrigues Island lies at the eastern end of the Rodrigues Ridge, a 450-km, east-trending lineament that intersects the main hotspot track perpendicularly just north of Mauritius. It is now known from extensive dredging and surveying during Darwin site-survey cruise $21 / 87$ that the Rodrigues Ridge is composed entirely of basaltic rocks. Rodrigues Island is built of olivine basalts that erupted about 1.5 Ma (McDougall, 1971). Dredged rocks from five sites distributed along the ridge yield radiometric ages that range from 8 to $10 \mathrm{Ma}\left({ }^{40} \mathrm{Ar} /{ }^{39} \mathrm{Ar}\right.$ analyses; R. A. Duncan, unpubl. data, 1989) with no apparent age progression. Apparently, the entire Rodrigues Ridge was built simultaneously just before the earliest volcanism at Mauritius; the younger Rodrigues Island activity must then be considered a rejuvenescent phase. Geophysical surveys (gravity and multichannel seismic reflection; A. N. Baxter, unpubl. data, 1989) may provide an explanation for the extent and peculiar orientation of this apophysis of the main volcanic trend.

The Mascarene Plateau and the Chagos-Maldives-Laccadives ridge system are the proposed northward continuation of this province. Carbonate bank and reef deposits cover the central portions of these plateaus, up to $2 \mathrm{~km}$ thick (Meyerhoff and Kamen-Kaye, 1981); consequently, drilling by JOIDES Resolution was located on the shoulder of the ridges to penetrate presumed volcanic rocks through principally pelagic sediments. Drilling at seven sites (three industry wells on the Nazareth, Saya de Malha, and Maldives platforms and four Leg 115 sites) has now established that volcanic rocks underlie the whole ridge system. Submarine eruptions rapidly built up volcanoes, often into subaerial islands (see individual site descriptions in Backman, Duncan, et al., 1988; Meyerhoff and Kamen-Kaye, 1981), that eroded to sea level and subsided as the oceanic lithosphere cooled, accumulated sediments, and adjusted to the weight of the new load (Simmons, this volume).

\section{FIXED HOTSPOTS, PLATE RECONSTRUCTIONS, AND TRUE POLAR WANDER}

Duncan and Hargraves (this volume) report ${ }^{40} \mathrm{Ar} /{ }^{39} \mathrm{Ar}$ radiometric age determinations from volcanic rocks recovered from six of the drill sites. These dates show a clear north-to-south progression in the age of volcanic activity along the system of ridges, which strongly supports the hotspot model. Because Indian Plate velocities were so high in the Late Cretaceous and early Tertiary (e.g., Klootwijk and Peirce, 1979), the dramatically linear Chagos-Maldives-Laccadives ridges and parallel 
Ninetyeast Ridge sections of the traces provide a particularly stringent test of motion between hotspots. We can examine the proposition that the Réunion and Kerguelen hotspots have been stationary with respect to other prominent hotspots by means of the test prescribed by Morgan (1981) and Duncan (1981). To do this, we first deduce the motion of the African Plate over hotspots in the South Atlantic from well-documented volcanic lineaments, such as the Tristan da Cunha hotspot and its trace, the Walvis Ridge (O'Connor and Duncan, 1984, in press), consistent with the geometrical limits imposed by other traces such as the St. Helena-Cameroon, the Bouvet-Agulhas Plateau, and the Marion-Madagascar Rise lines (Fig. 2). Next, we add the relative motion of the Indian Plate away from the African Plate for the last 120 m.y., based on seafloor-spreading data (e.g., Molnar et al., 1987; Besse and Courtillot, 1988).

The result is the predicted motion of the Indian Plate with respect to the starting set of hotspots underlying the South Atlantic region. If the Indian region hotspots have not moved much in relation to their Atlantic cousins, the predicted plate motion should match the direction and age of volcanism determined from the two hotspot tracks. From Figure 2, it is clear that the geometry and new age estimates from sites along both hotspot tracks are in excellent agreement with those required by the stationary hotspot model. Uncertainties in plate motions can be calculated with the Molnar and Stock (1985) approach. Molnar and Stock (1987) have estimated uncertainties in plate positions stemming from Africa-India relative motion data to be on the order of $1^{\circ}$ (i.e., about $100 \mathrm{~km}$ ) for the early Tertiary. Hence, the maximum motion allowed between the Atlantic and Indian hotspots is less than $2 \mathrm{~mm} / \mathrm{yr}$, which is effectively motionless, compared with typical plate velocities.

\section{Western Indian Ocean Basin Development through Tertiary Time}

Hotspots in this region, therefore, constitute a fixed mantle reference frame that very conveniently records Indian Ocean ba-

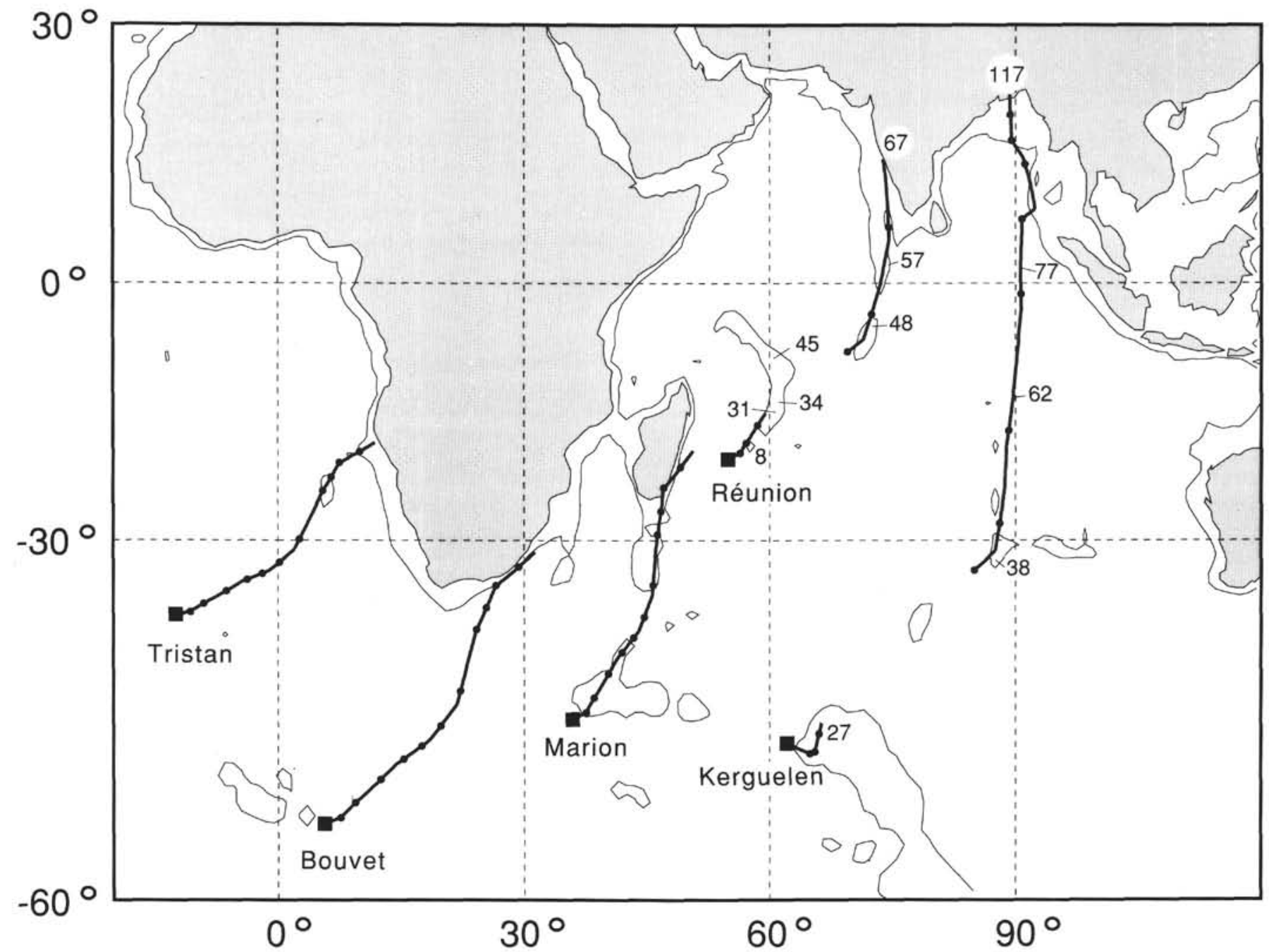

Figure 2. Computer-modeled, hotspot tracks are calculated assuming hotspots are stationary. The predicted trails (dots are 10-m.y. increments in volcano age) were determined from African Plate motion over South Atlantic hotspots (principally from dated sites on the Walvis Ridge), and relative motion between the Indian and African plates. A complete set of rotation poles is given in O'Connor and Duncan (in press). These compare well with the actual lineaments and documented ages (Ma) of volcanic activity along the Réunion and Kerguelen hotspot tracks (Duncan, 1978; Baksi, 1986). Hence, Atlantic and Indian ocean hotspots have remained fixed relative to one another for at least the last $100 \mathrm{~m}$.y. Flood basalts at the northern ends of the Réunion and Kerguelen tracks resulted from hotspot initiation. The Karoo flood basalts in southern Africa relate to the Marion hotspot, which burst to life at about $195 \mathrm{Ma}$ (Morgan, 1981), much earlier than the volcanic history illustrated here. 
sin evolution for Late Cretaceous through Tertiary time. Combining the drilling site ages with seafloor-spreading data (Schlich, 1982; Ségoufin and Patriat, 1981; Patriat et al., 1982, 1985) allows reconstruction of western Indian Ocean plate positions and boundaries for times of prominent magnetic anomalies (Figs. 3-6). In these reconstructions the position of Africa was calcu-

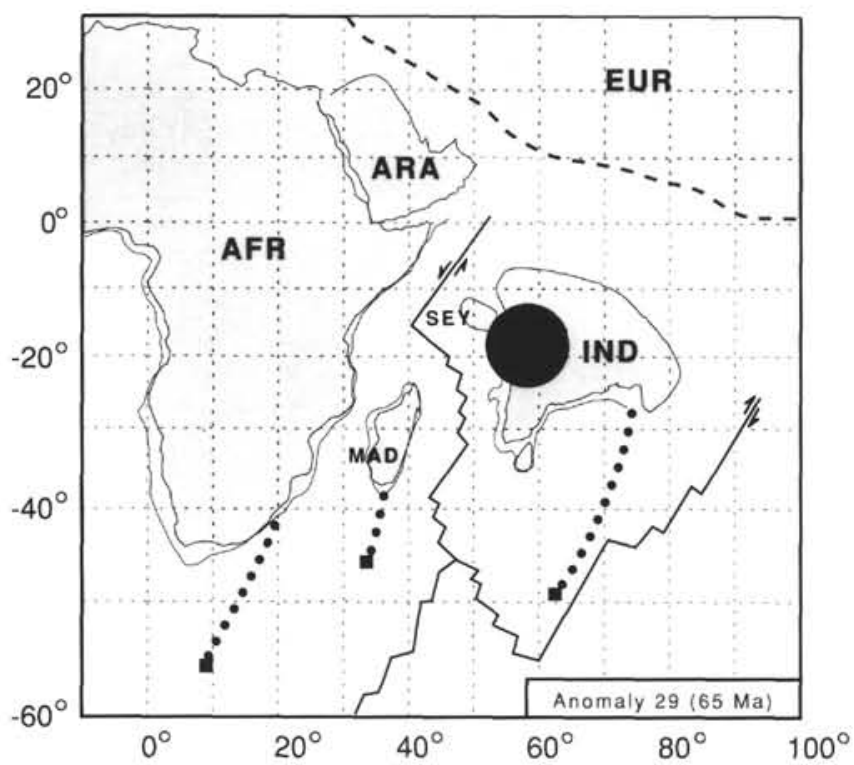

Figure 3. Paleogeographic reconstruction of the western Indian Ocean for $65 \mathrm{Ma}$ (Anomaly 29 time). Dotted paths describe the earlier track of the Kerguelen hotspot. The Réunion hotspot began with a rapid eruption of massive volumes of the Deccan flood basalts, shown by the dark circle, coincident with the time of the Cretaceous/Tertiary boundary. Site 707 formed at this time, as part of the western Deccan province, southeast of the Seychelles block.

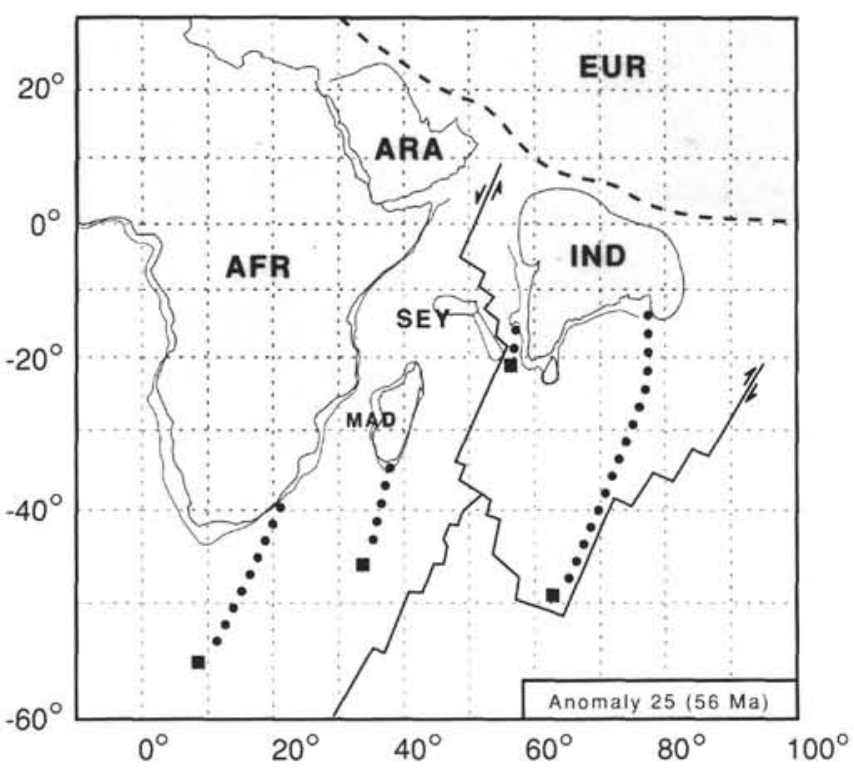

Figure 4. Paleogeographic reconstruction of the western Indian Ocean for $56 \mathrm{Ma}$ (Anomaly 25 time). Volcanic activity over the Réunion hotspot built the island sampled at Site 715. India and Arabia are close to colliding with Eurasia. Heavy dotted paths describe the tracks of the two hotspots.

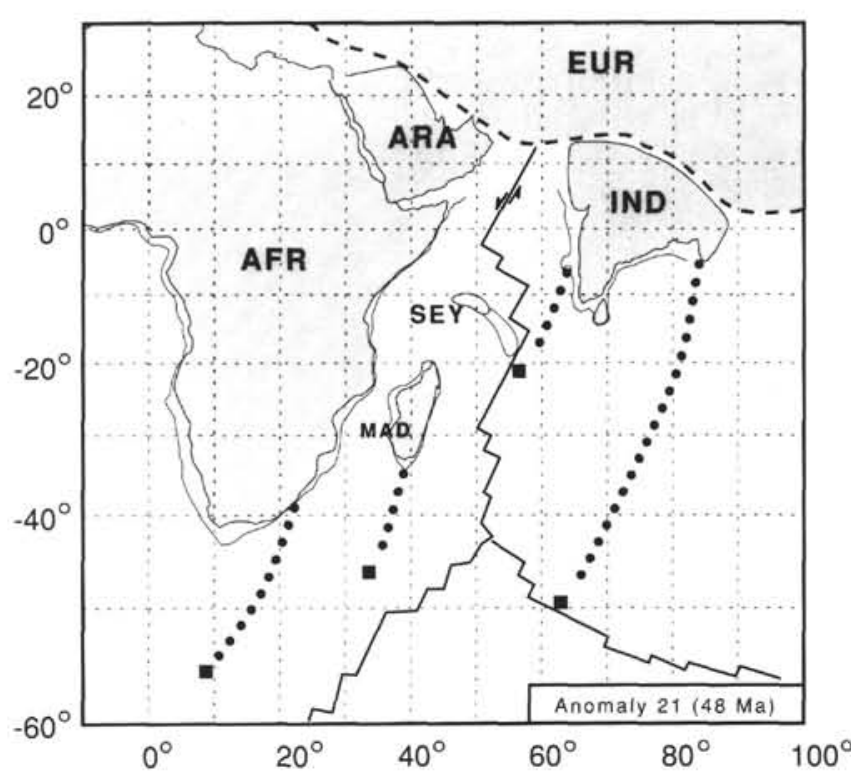

Figure 5. Paleogeographic reconstruction of the western Indian Ocean for $48 \mathrm{Ma}$ (Anomaly 21 time). Volcanic activity over the Réunion hotspot built the northern Chagos Bank (Site 713) and Saya de Malha Bank (industry well SM-1) at about this time. Heavy dotted paths describe the tracks of the two hotspots.

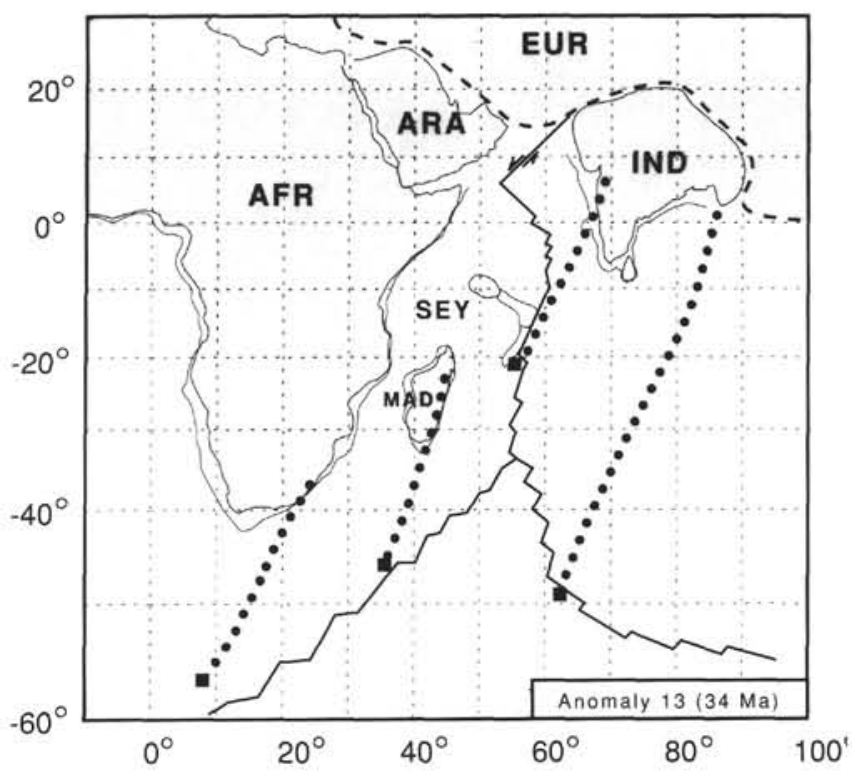

Figure 6. Paleogeographic reconstruction of the western Indian Ocean for $34 \mathrm{Ma}$ (Anomaly 13 time). Volcanic activity over the Réunion hotspot (Site 706) was centered on a segment of the central Indian spreading ridge. Migration of the spreading system to the northeast from this time to the present has isolated the hotspot beneath the African Plate, leading to the formation of the Mascarene Plateau and Islands. Heavy dotted paths describe the tracks of the two hotspots.

lated from the rotations proposed by O'Connor and Duncan (in press), whereas other plates and boundaries were located relative to Africa using the motions summarized by Besse and Courtillot (1988). The reconstructions show the same features noted by Besse and Courtillot (1988), except that plates are tied to the hotspot reference frame rather than to paleomagnetic latitudes and 
are therefore longitudinally "correct." Reconstruction ages were chosen to illustrate the plate tectonic regime at the times of the volcanic activity sampled by Leg 115 drilling.

India separated from Madagascar at $83 \mathrm{Ma}$ and moved rapidly northward, closing the Tethys Ocean. Active hotspots at the present coordinates of the Bouvet, Marion, and Kerguelen islands left traces along the Agulhas Plateau, the Madagascar Rise, and the north central Ninetyeast Ridge, respectively. Just before $65 \mathrm{Ma}$, the Réunion hotspot burst to life with massive eruptions of predominantly tholeiitic flood basalts in western India. The first plate reconstruction (Fig. 3) is for this time. This volcanic province, termed the Deccan Traps, is now a thick sequence of flat-lying basalt flows covering almost $500,000 \mathrm{~km}^{2}$. At its greatest thickness the section is over $2,000 \mathrm{~m}$. Including correlative basalts identified offshore (Arabian Sea) and lavas probably eroded, the original volume of the province may have exceeded $1.5 \times 10^{6} \mathrm{~km}^{3}$ (Courtillot et al., 1986).

Several lines of evidence indicate that most of this enormous quantity of basalt was erupted rapidly. Interflow sedimentary beds, lateritic weathering, and erosional unconformities are scarce (Mahoney, 1988). For the most part, the flows are reversely magnetized, and only two polarity reversals (N-R-N) were identified in the entire sequence (Courtillot et al., 1986). Radiometric ages $\left({ }^{40} \mathrm{Ar} /{ }^{39} \mathrm{Ar}\right.$ incremental heating method) show that the Deccan volcanism occurred sometime between 65 and $69 \mathrm{Ma}$ (Duncan and Pyle, 1988; Courtillot et al., 1988; Baksi and Kunk, 1988). Combining the magnetostratigraphic (which indicate a very brief duration of volcanism) and absolute age data, it follows that the Deccan basalts may have accumulated in as little as 0.5 m.y. at the Cretaceous/Tertiary boundary (Jaeger et al., 1989). The average eruption rate during Deccan volcanism was then close to $3 \mathrm{~km}^{3} / \mathrm{yr}$, or 2 orders of magnitude greater than at the hotspot today.

Richards et al. (1989) have proposed a general model for hotspot initiation in flood basalt volcanism. In this scheme plumes develop as density instabilities deep in the mantle (e.g., the core/ mantle boundary). Initially, a plume forms a large "head," which establishes a conduit as it rises diapirically to the surface (Whitehead and Luther, 1975). When the plume head reaches the base of the lithosphere, rapid, voluminous decompression melting occurs (an excess plume temperature of $250^{\circ}-300^{\circ} \mathrm{C}$ could generate $10 \%-20 \%$ melt fraction) and lithospheric thinning and extension results. This event produces flood basalt volcanism within continents or ocean basins, or presaging rifting at plate margins. Once melting from the plume head is exhausted, a continuing supply of deep mantle material from the plume "tail" (conduit) maintains the hotspot, which produces the more familiar and far less catastrophic linear series of volcanic centers.

This model requires that all hotspots begin with flood basalt volcanism, and many currently active hotspots can be traced back to such provinces, for example, from Tristan da Cunha through the Rio Grande Rise to the Parana basalts, from Marion through Madagascar and back southwest to the Karoo basalts, and from Iceland to the North Atlantic Tertiary basalts (Morgan, 1981; Richards et al., 1989). One of the major contributions of Leg 115 drilling was to tie Deccan flood basalts unequivocally to the birth of the Réunion hotspot. As a result of Leg 121 drilling, it now seems undeniable that the Kerguelen hotspot also began with flood basalt volcanism at the Rajmahal Traps, eastern India, at about $117 \mathrm{Ma}$ (Baksi, 1986); a large portion of this province is probably preserved as the Southern and Central Kerguelen plateaus.

Shortly after the Deccan basalts erupted, the central Indian spreading ridge jumped from the Madagascar Basin north to the western margin of India, where the Seychelles Bank and a small western portion of the Deccan province, including that section of the Mascarene Plateau penetrated by drilling at Site
707 (64 Ma), rifted away from India and were welded to the African Plate. Surprisingly, India's northward velocity over the mantle did not slow for the flood basalt event or for the ridge jump, staying constant near $13 \mathrm{~cm} / \mathrm{yr}$ between 83 and $48 \mathrm{Ma}$ (Duncan and Hargraves, this volume).

By Anomaly 25 time ( $56 \mathrm{Ma}$ ), seafloor spreading had opened a small basin between India and the Seychelles Bank (Fig. 4). The hotspot at this time was building the volcanic island drilled into at Site 715 . The precise positions of spreading ridge segments and transforms along the Central Indian Ridge are not known, but a long left-lateral transform boundary must have existed just to the west of the hotspot that connected spreading in the Arabian Sea with spreading near and south of the Indian Ocean triple junction. Trace element compositions of basalts from Site 715 suggest that the hotspot was not located at a spreading ridge because there is little evidence for large-scale mixing with magmas of a mid-ocean-ridge (MORB) origin (Fisk et al., 1989). The collisions of India and Africa (Arabia) with Eurasia began shortly after this time (Besse et al., 1984), established from stratigraphic, structural, and paleomagnetic evidence.

Figure 5 illustrates a plate reconstruction for $48 \mathrm{Ma}$ (Anomaly 21), the age of Site 713 volcanic activity. Significant crustal shortening took place along the collisional boundary (Besse and Courtillot, 1988), and there was a marked deceleration in India's northward velocity from this time to the present (Duncan and Hargraves, this volume). Spreading in the northeast Indian Ocean ceased, and a vigorous phase of plate divergence began to separate Australia from Antarctica. Thus, the Australian and Indian plates were welded and afterward acted as a single plate. The Réunion hotspot built the northern Chagos Bank (49 Ma) and much of the Saya de Malha Bank (47 Ma) near or on a spreading segment of the Central Indian Ridge. Geochemical data from Site 713 basalts indicate significant mixing of melts from hotspot and MORB upper-mantle sources (Fisk et al., 1989). The Kerguelen hotspot, lying just north of the Southeast Indian spreading ridge, constructed the southern section of the Ninetyeast Ridge.

At $34 \mathrm{Ma}$ (Anomaly 13 time), the Réunion hotspot was centered under a segment of the Central Indian Ridge (Fig. 6), supplying melts to the Nazareth Bank (Site 706) as well as to the southern Chagos Bank. Basalts from Site 706 show distinct contributions from hotspot and MORB sources (Fisk et al., 1989; Baxter, this volume; White et al., this volume). The Indian Ocean spreading ridge system migrated northeastward first over the Kerguelen hotspot (around $38 \mathrm{Ma}$ ) and then the Réunion hotspot $(34 \mathrm{Ma})$. From these times to the present, each hotspot has been in an intraplate position: Kerguelen building the northern Kerguelen Plateau during very slow clockwise rotation of the Antarctic plate, and Réunion forming the eastern Mascarene Plateau as the African plate moved northeastward at $3 \mathrm{~cm} / \mathrm{yr}$.

\section{Paleolatitudes of Leg 115 Sites: True Polar Wander?}

If we accept the conclusion from the beginning of this section that mantle plumes are stationary, to within $2 \mathrm{~mm} / \mathrm{yr}$, over periods as long as 100 m.y., then the volcanic traces left by hotspots record the past histories of plate motions over the lower mantle. This mantle reference frame is independent of the paleomagnetic reference frame and has certain advantages: it does not depend on the assumption of the geocentric axial dipole field, and it resolves east-west motion that is not detected in paleomagnetic studies. Differential motion between the mantle and the spin axis can, in principle, be determined by comparing plate motions recorded by the hotspot and paleomagnetic reference frames. Such motion has been termed "true polar wander" (distinguished from apparent polar wander of the geomagnetic axis inferred from time sequences of paleomagnetic field directions for given plates). True polar wander could occur through mass 
redistribution (e.g., mantle convection and plate motions) sufficient to shift the entire body relative to its spin axis (Goldreich and Toomre, 1969).

In the absence of true polar wander, mantle plumes would not move with respect to the geomagnetic (= spin) axis. Hence, every volcano generated along a given hotspot track would record the magnetic inclination, expressed as paleolatitude, of the present hotspot activity site. If such measured paleolatitudes are not constant, it follows that the mantle reference frame moves relative to the spin axis, which is true polar wander. Vandamme and Courtillot (this volume) and Schneider and Kent (this volume) present paleolatitude data for basalts and sediments recovered at Leg 115 drilling sites. Results from three sites (706, 707, and 715) appear to be reliable and, together with magnetic studies of the Deccan basalts (Courtillot et al., 1986), indicate a possible, slow $(8 \mathrm{~mm} / \mathrm{yr})$ northward motion of the Réunion hotspot since its birth at $66 \mathrm{Ma}$ (Fig. 7).

The calculated true polar wander is just barely significant at the $\alpha_{95}$ confidence level of the paleomagnetic data. Considering the uncertainties in size and precise location of the hotspot during Deccan volcanism, the paleolatitudes may not be significantly different. However, the direction and magnitude $\left(5^{\circ}-6^{\circ}\right)$ of inferred mantle motion is consistent with other comparisons of the hotspot and paleomagnetic reference frames (see Courtillot and Besse, 1987, for a summary). Of particular interest are magnetic studies of basalts recovered by DSDP drilling at Suiko Seamount (Site 433) that yielded a 65-Ma paleolatitude for the Hawaiian hotspot of $27.1^{\circ} \mathrm{N} \pm 3.4^{\circ}$ (Kono, 1980), requiring some $8^{\circ}$ southward motion of the hotspot through Tertiary time. Paleolatitudes of younger sites along the Hawaiian-Emperor chain are not significantly different from the present hotspot position $\left(19^{\circ} \mathrm{N}\right)$. These data (Fig. 7) are consistent with the slow northward motion of hotspots in the Indian Ocean and the southward motion of hotspots in the Pacific, which would be the case if the whole mantle rotated $8^{\circ}$ clockwise about a pole emerging on the equator near $90^{\circ} \mathrm{E}$ (Courtillot and Besse, 1987).

\section{GEOCHEMICAL VARIATIONS ALONG THE RÉUNIQN HOTSPOT TRACK}

A major objective of Leg 115 basement drilling was to sample a time sequence of volcanic products from Réunion hotspot activity to examine compositional changes from flood basalts to oceanic-island volcanism. The seamount and island basalts of other similarly long-lived hotspots are characterized by remarkable uniformity in composition (e.g., the Hawaiian-Emperor chain [Lanphere et al., 1980] and the Louisville Ridge [Cheng et al., 1988]), but certain isotopic and trace element ratios indicate that subtle changes in the mantle source for melt production may occur with time (e.g., Stille et al., 1986). Basalt compositions from the end points of the Deccan-Réunion chain (Cox and Hawkesworth, 1985; Fisk et al., 1988) also indicate that there was a change in the mantle material supplied to the hotspot through Tertiary time. Papers in this volume describe geochemical, mineralogic, and lithologic variations along the hotspot track.

Baxter (this volume) and Fisk et al. (1989) have summarized the evidence for major and trace element variations. The major element compositions (coupled with petrographic observations) show that volcanic rocks all along the lineament are predominantly oceanic-island tholeiites with variation controlled principally by low-pressure olivine and plagioclase fractionation. The abundance of incompatible elements (e.g., K, Ti, and $\mathrm{Zr}$ ) in parental magmas, however, appears to increase with time, from Deccan to Réunion sites. Moreover, trace element abundance ratios that are generally insensitive to variations in partial melting and fractional crystallization (e.g., $\mathrm{Ba} / \mathrm{Ti}, \mathrm{Nb} / \mathrm{Y}$, and $\mathrm{Zr}$ / $\mathrm{Nb})$ show systematic increases from north to south. White et al.
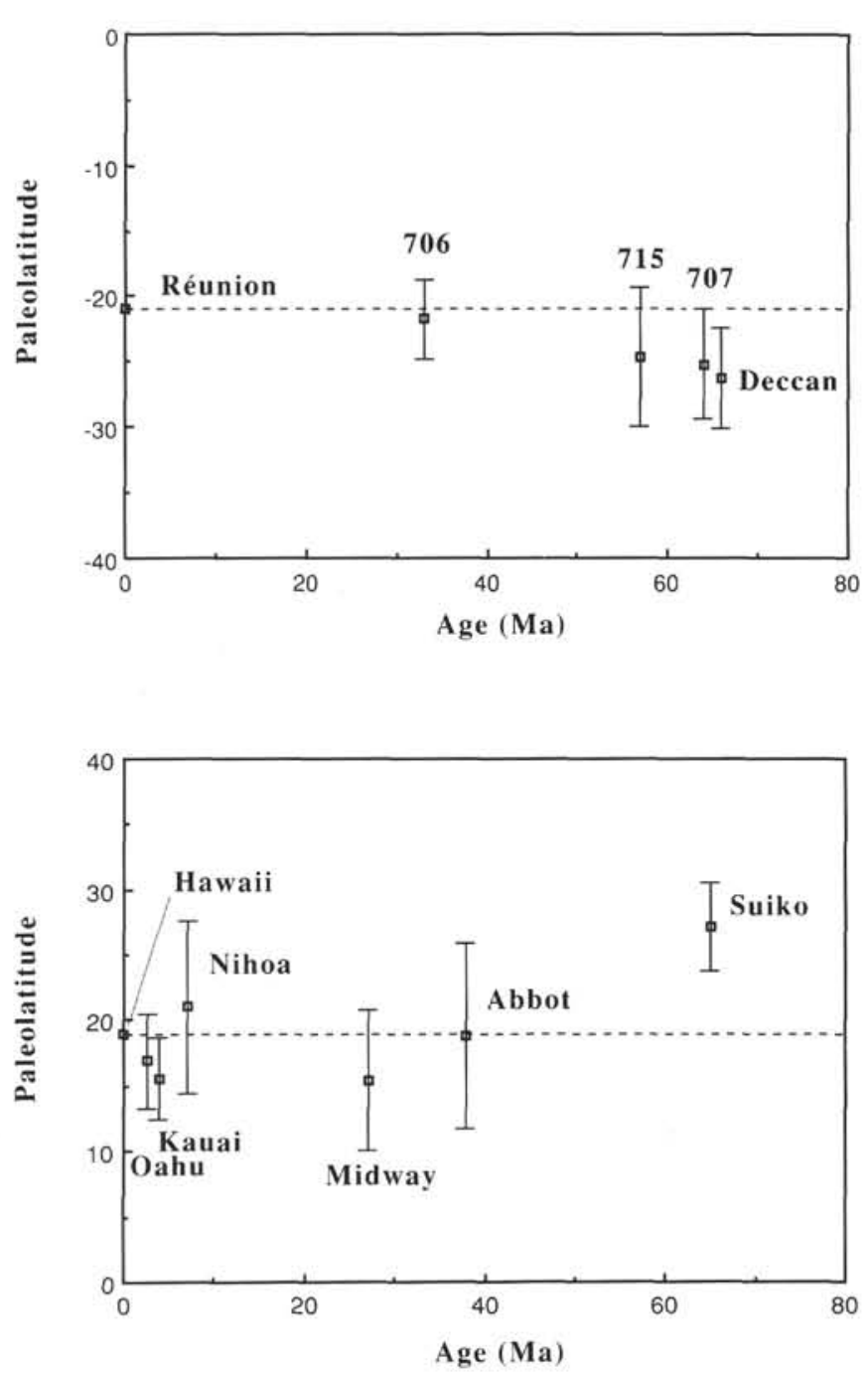

Figure 7. Paleolatitudes of sample sites from the Réunion hotspot track, with $\alpha_{95}$ confidence limits, as a function of time. These revised estimates from Schneider and Kent (this volume) and Vandamme and Courtillot (this volume) supersede those in the Initial Reports (Backman, Duncan, et al., 1988). These data indicate a slow northward motion of the Réunion hotspot relative to the geomagnetic axis of $5^{\circ}-6^{\circ}$ since $65 \mathrm{Ma}$. For comparison, sample sites from the Hawaiian-Emperor chain $(\mathrm{Pa}$ cific Ocean) show a southward motion of the Hawaiian hotspot of $8^{\circ}$ for the same period (Kono, 1980). The results are consistent with a small component of true polar wander (i.e., motion of the entire earth with respect to the spin axis).

(this volume) have determined the isotopic compositions $(\mathrm{Sr}$, $\mathrm{Nd}$, and $\mathrm{Pb}$ ) of Leg 115 basalts, which are distinct from both Réunion and Deccan basalts. There is a clear trend toward higher ${ }^{87} \mathrm{Sr} /{ }^{86} \mathrm{Sr}$ and ${ }^{206} \mathrm{~Pb} /{ }^{204} \mathrm{~Pb}$ and lower $\epsilon_{\mathrm{Nd}}$ with time (White et al., this volume, figs. 5 and 6 ). This pattern is correlated with a change from a near-ridge to an intraplate hotspot setting as well as a dramatic drop in magma production rate (Deccan to Réunion).

There may be several causes for the temporal variations in basalt compositions produced from the Réunion hotspot: (1) the plate tectonic environment in which the magmas erupted; (2) the effects of decreasing degrees of partial melting of plume material, which is heterogeneous on a small scale; and (3) changes in the composition of the plume itself. As previously discussed, plate reconstructions place the hotspot at a spreading ridge dur- 
ing volcanic activity at Sites 706 and 707 . Sites 713 and industry-drilling site SM-1 formed close to a spreading center, whereas Site 715 formed in more of an intraplate setting. Réunion and Mauritius were built far from the Central Indian Ridge. Hence, we could expect that basalt compositions from Sites 706 and 707 would show the greatest effect of plume material dilution with asthenospheric melts (MORB-like), whereas Site 715 basalts would be more like Réunion basalts. Some geochemical parameters $(\mathrm{Ba} / \mathrm{Ti}$ and $\mathrm{Zr} / \mathrm{Nb})$ are consistent with these predictions whereas others ( $\mathrm{Sr}, \mathrm{Nd}$, and $\mathrm{Pb}$ isotopic ratios) are not. Contributions to melting from MORB-like source materials were certainly observed in Leg 115 basalt compositions, but they appear to diminish smoothly with time.

White et al. (this volume) concluded that, although decreasing degrees of partial melting may increase the proportions of incompatible elements and "enriched" isotopic ratios in hotspot magmas derived from compositionally heterogeneous plume material, the most plausible explanation for the observed geochemical variations is decreasing entrainment of asthenosphere by the rising plume. In the diapir model for plume initiation and flood basalt volcanism (Richards et al., 1989), the hot, low-viscosity, deeper mantle plume material will warm and entrain the upper-mantle material through which it rises (Griffiths, 1986). An extensive examination of the Deccan basalts has shown that these magmas were a blend of plume (represented by Réunion basalt compositions) and Indian Ocean MORB mantle, variably contaminated with continental lithosphere (e.g., Mahoney, 1988). The sheer size of the Deccan flood basalt event $(1.5 \times$ $10^{6} \mathrm{~km}^{3}$ of lavas erupted in $0.5 \mathrm{~m} . \mathrm{y}$.) indicates that a substantial region of the upper mantle beneath western India was involved in melting. Once the plume head had melted, the established plume conduit (tail) did not foster the same degree of entrainment of surrounding mantle, and the hotspot trail then formed from a much smaller scale of melting that involved progressively less MORB influence.

\section{SUMMARY}

The volcanic record of the Réunion hotspot offers several new insights on the life cycle and behavior of mantle plumes. Drilling on the Mascarene Plateau and the Chagos-Maldives ridges has demonstrated the volcanic continuity of the proposed trace of the Réunion hotspot on the Indian and African plates. A most important connection between flood basalt volcanism in western India (the Deccan Traps) and the initiation of Réunion hotspot activity has now been firmly established and used in a generalized model of plume initiation from deep-mantle density instabilities (Richards et al., 1989). Volumetric and compositional variations along the hotspot track support the initial mixing and entrainment of asthenosphere within a large plume head that rapidly melted over a large region to produce the flood basalt event. Smaller volumes of plume material continued to rise within the conduit established by the initial diapir, but opportunities for mixing with the upper mantle were much more limited and the hotspot volcanic products reflect a progressively more plume-like composition with time. From initial results (Peirce, Weissel, et al., 1989), it is likely that the Kerguelen hotspot has evolved in a similar sequence, although over a longer time span.

The high density of radiometrically dated sample sites and the clear, linear volcanic traces produced by rapid plate velocities in early Tertiary time allow a stringent evaluation of the magnitude of the motion between hotspots. It appears that hotspots in the Atlantic and Indian ocean basins have been virtually stationary ( $<2 \mathrm{~mm} / \mathrm{yr}$ relative motion) for periods as long as $100 \mathrm{~m}$.y. It follows that the underlying plumes have not been affected very much by the horizontal upper-mantle flow; this is surprising given that vigorous spreading ridges have crossed over both the Réunion and Kerguelen hotspots. A barely significant component of true polar wander $\left(5^{\circ}-6^{\circ}\right.$ since $\left.65 \mathrm{Ma}\right)$ can be distinguished by comparing hotspot and paleomagnetic reference frames. This is, however, consistent with other perceived motions of hotspots with respect to the geomagnetic axis.

Basement drilling during Leg 115 has shown the value of detailed sampling of prominent hotspot tracks. In the future, similar coverage should be achieved on the older portions (i.e., Cretaceous and early Tertiary) of several oceanic lineaments, such as the Emperor Seamounts and the Louisville and Walvis ridges. Ocean drilling should also focus on the major oceanic plateaus (e.g., Ontong Java) to assess whether or not these are oceanic equivalents of continental flood basalt events, signaling the beginning of hotspot activity.

\section{ACKNOWLEDGMENTS}

I thank the Shipboard Scientific Party, the ODP technical and logistics personnel, and the crew and drilling operations staff of the JOIDES Resolution for their cooperation, professionalism, and enthusiasm during Leg 115. Computer-assisted illustrations were produced by P. Roperch. This research was supported by funds from the JOI U.S. Science Advisory Committee and the National Science Foundation (Grant No. OCE-8812143).

\section{REFERENCES}

Backman, J., Duncan, R. A., et al., 1988. Proc. ODP, Init. Repts., 115: College Station, TX (Ocean Drilling Program).

Baksi, A. K., 1986. ${ }^{40} \mathrm{Ar} /{ }^{39} \mathrm{Ar}$ incremental heating study of whole-rock samples from the Rajmahal and Bengal traps, eastern India. Terra Cognita, 6:161. (Abstract)

Baksi, A. K., and Kunk, M. J., 1988. The age of initial volcanism in the Deccan Traps, India: preliminary ${ }^{40} \mathrm{Ar} /{ }^{39} \mathrm{Ar}$ age spectrum dating results. Eos, 69(29):732. (Abstract)

Besse, J., and Courtillot, V., 1988. Paleogeographic maps of the continents bordering the Indian Ocean since the Early Jurassic. J. Geophys. Res., 93:11,791-11,808.

Besse, J., Courtillot, V., Pozzi, J. P., Westphal, M., and Zhou, Y. X., 1984. Paleomagnetic estimates of crustal shortening in the Himalayan thrusts and Zangbo suture. Nature, 311:621-626.

Cheng, Q., Park, K.-H., Macdougall, J. D., Zindler, A., Lugmair, G. W., Staudigel, H., Hawkins, J., and Lonsdale, P., 1988. Isotopic evidence for a hotspot origin of the Louisville Seamount chain. In Keating, B. H., Fryer, P., Batiza, B., and Boehlert, G. W. (Eds.), Seamounts, Islands, and Atolls. Am. Geophys. Union Monogr., 43: 283-296.

Courtillot, V., and Besse, J., 1987. Magnetic field reversals, polar wander, and core-mantle coupling. Science, 237:1140-1147.

Courtillot, V., Besse, J., Vandamme, D., Montigny, R., Jaeger, J.-J., and Capetta, H., 1986. Deccan flood basalts at the Cretaceous/Tertiary boundary? Earth Planet. Sci. Lett., 80:361-374.

Courtillot, V., Féraud, G., Maluski, H., Vandamme, D., Moreau, M. G., and Besse, J., 1988. Deccan flood basalts and the Cretaceous/Tertiary boundary. Nature, 333:843-846.

Cox, K. G., and Hawkesworth, C. J., 1985. Geochemical stratigraphy of the Deccan Traps at Mahabaleshwar, Western Ghats, India, with implications for open-system magmatic processes. J. Petrol., 26:355377.

Duncan, R. A., 1978. Geochronology of basalts from the Ninetyeast Ridge and continental dispersion in the eastern Indian Ocean. $J$. Volcanol. Geotherm. Res., 4:283-305.

1981. Hotspots in the southern oceans-an absolute frame of reference for motion of the Gondwana continents. Tectonophysics, 74:29-42.

Duncan, R. A., and Pyle, D. G., 1988. Rapid eruption of the Deccan flood basalts at the Cretaceous/Tertiary boundary. Nature, 333:841843.

Fisk, M. R., Duncan, R. A., Baxter, A. N., Greenough, J. D., Hargraves, R. B., Tatsumi, Y., and Shipboard Scientific Party, 1989. Reunion hotspot magma chemistry over the past 65 m.y.: results from Leg 115 of the Ocean Drilling Program. Geology, 17:934-937. 
Fisk, M. R., Upton, B.G.J., Ford, C. E., and White, W. M., 1988. Geochemical and experimental study of the genesis of magmas of Réunion Island, Indian Ocean. J. Geophys. Res., 93:4933-4950.

Gillot, P.-Y., and Nativel, P., 1989. Eruptive history of the Piton de la Fournaise volcano, Réunion Island, Indian Ocean. J. Volcanol. Geotherm. Res., 36:53-65.

Goldreich, P., and Toomre, A., 1969. Some remarks on polar wandering. J. Geophys. Res., 74:2555-2567.

Griffiths, R. W., 1986. The differing effects of compositional and thermal buoyancies on the evolution of mantle diapirs. Phys. Earth Planet. Inter., 43:261-273.

Jaeger, J. J., Courtillot, V., and Tapponier, P., 1989. Paleontological view of the ages of the Deccan Traps, the Cretaceous/Tertiary boundary, and the India-Asia collision. Geology, 17:316-319.

Klootwijk, C. T., and Peirce, J. W., 1979. India's and Australia's pole path since the late Mesozoic and the India-Asia collision. Nature, 282:605-607.

Kono, M., 1980. Paleomagnetism of DSDP Leg 55 basalts and implications for the tectonics of the Pacific plate. In Jackson, E. D., Koizumi, I., et al., Init. Repts. DSDP, 55: Washington (U.S. Govt. Printing Office), 737-752.

Lanphere, M. A., Dalrymple, G. B., and Clague, D. A., 1980. Rb-Sr systematics of basalts from the Hawaiian-Emperor volcanic chain. In Jackson, E. D., Koizumi, I., et al., Init. Repts. DSDP, 55: Washington (U.S. Govt. Printing Office), 695-705.

McDougall, I., 1971. The geochronology and evolution of the young volcanic island of Réunion, Indian Ocean. Geochim. Cosmochim. Acta, 35:261-270.

McKenzie, D. P., and Sclater, J. G., 1971. The evolution of the Indian Ocean since the Late Cretaceous. Geophys. J. R. Astron. Soc., 25: 437-528.

Mahoney, J. J., 1988. Deccan Traps. In Macdougall, J. D. (Ed.), Continental Flood Basalts: Dordrecht, The Netherlands (Kluwer Academic Publishers), 151-194.

Meyerhoff, A. A., and Kamen-Kaye, M., 1981. Petroleum prospects of Saya de Malha and Nazareth banks, Indian Ocean. AAPG Bull., 65: 1344-1347.

Molnar, P., Pardo-Casas, F., and Stock, J., 1987. The Cenozoic and Late Cretaceous evolution of the Indian Ocean basin: uncertainties in the reconstructed positions of the Indian, African and Antarctic plates. Basin Res., 1:23-40.

Molnar, P., and Stock, J., 1985. A method for bounding uncertainties in combined plate reconstructions. J. Geophys. Res., 90:12,537-12,544.

Morgan, W. J., 1981. Hotspot tracks and the opening of the Atlantic and Indian oceans. In Emiliani, C. (Ed.), The Sea (Vol. 7): The Oceanic Lithosphere: New York (Wiley-Interscience), 443-487.
1987. Relative motions of hotspots in the Pacific, Atlantic and Indian oceans since Late Cretaceous time. Nature, 327:587-591.

O'Connor, J. M., and Duncan, R. A., 1984. Radiometric age determinations for volcanic rocks from the Walvis Ridge and implications for plate reconstructions around the southern Atlantic Ocean. Eos, 65(45):1076. (Abstract)

, in press. Evolution of the Walvis Ridge and Rio Grande Rise hotspot system: implications for African and South American plate motions over hotspots. J. Geophys. Res.

Patriat, P., Ségoufin, J., Goslin, J., and Beuzart, P., 1985. Relative positions of Africa and Antarctica in the Upper Cretaceous: evidence for non-stationary behaviour of fracture zones. Earth Planet. Sci. Lett., 75:204-214.

Patriat, P., Ségoufin, J., Schlich, R., Goslin, J., Auzende, J. M., Beuzart, P., Bonnin, J., and Olivet, J. L., 1982. Les mouvements relatifs de l'Inde, de l'Afrique et de 1'Eurasie. Bull. Bur. Rech. Geol. Min. (Fr.), 24:363-373.

Peirce, J., Weissel, J., et al., 1989. Proc. ODP, Init. Repts., 121: College Station, TX (Ocean Drilling Program).

Richards, M. A., Duncan, R. A., and Courtillot, V. E., 1989. Flood basalts and hotspot tracks: plume heads and tails. Science, 246:103107.

Schlich, R., 1982. The Indian Ocean: aseismic ridges, spreading centers and oceanic ridges. In Nairn, A.E.M., and Stehli, F. G. (Eds.), The Ocean Basins and Margins (Vol. 6): The Indian Ocean: New York (Plenum Press), 51-147.

Ségoufin, J., and Patriat, P., 1981. Reconstitutions de l'Océan Indien occidental pour les époques des anomalies M21, M2 et 34. Paléoposition de Madagascar. Bull. Bur. Rech. Geol. Min. (Fr.), 23:605-607.

Stille, P., Unruh, D. M., and Tatsumoto, M., 1986. Pb, Sr, Nd, and Hf isotopic constraints on the origin of Hawaiian basalts and evidence for a unique mantle source. Geochim. Cosmochim. Acta, 50:23032319.

Ten Brink, U. S., Brocher, T. M., and Watts, A. B., 1986. The nature of the crust-mantle transition under the flexural moats flanking $\mathrm{Ha}$ waii. Eos, 67(16):371. (Abstract)

Whitehead, J. A., and Luther, D. S., 1975. Dynamics of laboratory diapir and plume models. J. Geophys. Res., 80:705-717.

Date of initial receipt: 16 October 1989

Date of acceptance: 12 January 1990

Ms 115B-206 